\title{
Influence of perylenediimide-pyrene supramolecular interactions on the stability of DNA-based hybrids: Importance of electrostatic complementarity
}

\author{
Christian B. Winiger, Simon M. Langenegger, Oleg Khorev and Robert Häner ${ }^{*}$
}

\author{
Full Research Paper \\ Address: \\ Department of Chemistry and Biochemistry, University of Bern, \\ Freiestrasse 3, CH-3012 Bern, Switzerland \\ Email: \\ Robert Häner ${ }^{*}$ - robert.haener@dcb.unibe.ch \\ * Corresponding author \\ Keywords: \\ DNA; hybridization; nucleic acids; perylenediimide; pyrene
}

\author{
Beilstein J. Org. Chem. 2014, 10, 1589-1595. \\ doi:10.3762/bjoc. 10.164 \\ Received: 10 April 2014 \\ Accepted: 17 June 2014 \\ Published: 11 July 2014 \\ This article is part of the Thematic Series "Nucleic acid chemistry". \\ Guest Editor: H.-A. Wagenknecht
}

(c) 2014 Winiger et al; licensee Beilstein-Institut.

License and terms: see end of document.

\begin{abstract}
Aromatic $\pi-\pi$ stacking interactions are ubiquitous in nature, medicinal chemistry and materials sciences. They play a crucial role in the stacking of nucleobases, thus stabilising the DNA double helix. The following paper describes a series of chimeric DNA-polycyclic aromatic hydrocarbon (PAH) hybrids. The PAH building blocks are electron-rich pyrene and electron-poor perylenediimide (PDI), and were incorporated into complementary DNA strands. The hybrids contain different numbers of pyrene-PDI interactions that were found to directly influence duplex stability. As the pyrene-PDI ratio approaches 1:1, the stability of the duplexes increases with an average value of $7.5^{\circ} \mathrm{C}$ per pyrene-PDI supramolecular interaction indicating the importance of electrostatic complementarity for aromatic $\pi-\pi$ stacking interactions.
\end{abstract}

\section{Introduction}

When two aromatic molecules are in close proximity they often have a tendency to interact non-covalently in a face-to-face stacking arrangement. Face-centered, parallel aromatic $\pi-\pi$ stacking interactions have been studied and reviewed in great detail [1-5]. These interactions are especially important for polycyclic aromatic hydrocarbons (PAHs) [6,7]. The interaction is the result of solvophobicity, as well as van der Waals, electrostatic and charge transfer interactions that can lead to a thermodynamically favourable association [8]. It is an important interaction in biological systems, drug receptor interactions, materials sciences, and supramolecular chemistry [8-12]. Such interactions are strongly dependent on the electron density and distribution of the partners [2,9,13-16]. In particular, the interaction between electron-rich (donor) and electrondeficient (acceptor) aromatic rings results in stable aggregates [17-22].

In the DNA duplex, the interaction of the two complementary strands is governed mainly by aromatic $\pi-\pi$ stacking interactions, hydrogen bonds, and electrostatic repulsion from the 
negatively-charged sugar phosphate backbone [10,23-28]. DNA can be regarded as an amphiphilic polymer in which aromatic residues are linked by negatively charged phosphodiester groups [29]. The importance of aromatic and hydrophobic factors for duplex stability was demonstrated by replacing the natural nucleobases by size expanded analogs [3035].

A classic example of polymeric donor-acceptor complexes are the aedamers (aromatic electron donor acceptor oligomers) pioneered by Iverson and coworkers [18,36,37]. They consist of face-to-face stacked electron-rich naphthalene and electron-poor naphthalenediimide (NDI) chromophores and belong to the broader area of foldamers [38].

DNA has been described as a molecular scaffold for arranging various types of chromophores [39-44]. Recently, we reported that oligoarenotides (oligomers with an alternating phosphodiester-aromatic hydrocarbon motif) exhibit similar structural properties as nucleic acids, and although the aromatic hydrocarbons cannot engage in any sort of Watson-Crick related hydrogen bonding, the individual strands interact via an interstrand stacking motif [45-48]. Herein we describe a series of DNA-based hybrids (Figure 1 and Table 1) containing electron-rich 1,8-dialkynylpyrenes (Y) and electron-poor perylenediimides (PDI, E).

PDIs (Figure 1A) are some of the most widely studied organic chromophores [49-52]. Moreover, we have reported on the aggregation and stacking properties of 1,8- and 1,6dialkynylpyrene [53,54]. Figure 1B shows the electrostatic potential surface of 1,8-diprop-1-ynylpyrene and $N, N^{\prime}$ dimethyl-PDI. The former is considerably more electron-rich/ higher electron density (red) than the latter, which is expected to favour an alternating aromatic $\pi-\pi$ stacking arrangement of $\mathbf{E}$ and $\mathbf{Y}$ due to electrostatic complementarity.

We show herein that duplex formation by our chimeric DNAoligoarenotide strands proceeds in a selective manner, the chromophores on opposite strands interdigitate and stack face-toface in an organised controlled assembly.

\section{Results and Discussion}

The principle of the system is illustrated in Figure 1. All oligomers are composed of a DNA part and a modified section containing a total of four PDIs (blue) and/or pyrenes (green). Oligomers 1-7 consisting of varying numbers of pyrene or PDI moieties covalently linked to complementary DNA strands were prepared by automated oligonucleotide synthesis using the previously described phosphoramidite pyrene [53] and PDI [55] building blocks.
Table 1: $T_{\mathrm{m}}$ values of the hybrids determined by thermal denaturation experiments. $^{a}$

\begin{tabular}{|c|c|c|c|}
\hline & Sequence & $T_{\mathrm{m}}\left({ }^{\circ} \mathrm{C}\right)$ & $\begin{array}{l}\text { Number of } \\
\text { pyrene-PDI } \\
\text { interactions }\end{array}$ \\
\hline Ref & $\begin{array}{l}\text { 5' GCGTTA } \\
\text { 3' CGCAAT }\end{array}$ & 13.0 & \\
\hline $\begin{array}{l}1 \\
2\end{array}$ & $\begin{array}{l}\text { 5‘ GCGTTA YYYY } \\
\text { 3‘ CGCAAT YYYY }\end{array}$ & 50.5 & 0 \\
\hline $\begin{array}{l}1 \\
3\end{array}$ & $\begin{array}{l}\text { 5‘ GCGTTA YYYY } \\
\text { 3‘ CGCAAT YYEY }\end{array}$ & 54.5 & 2 \\
\hline $\begin{array}{l}1 \\
4\end{array}$ & $\begin{array}{l}\text { 5‘ GCGTTA YYYY } \\
\text { 3‘ CGCAAT YEYE }\end{array}$ & 58.5 & 4 \\
\hline $\begin{array}{l}1 \\
5\end{array}$ & $\begin{array}{l}\text { 5' GCGTTA YYYY } \\
\text { 3‘ CGCAAT YEEE }\end{array}$ & 61.0 & 6 \\
\hline $\begin{array}{l}1 \\
6\end{array}$ & $\begin{array}{l}\text { 5‘ GCGTTA YYYY } \\
\text { 3‘ CGCAAT EEEE }\end{array}$ & 64.5 & 7 \\
\hline $\begin{array}{l}7 \\
2\end{array}$ & $\begin{array}{l}\text { 5‘ GCGTTA EEEE } \\
\text { 3‘ CGCAAT YYYY }\end{array}$ & 66.5 & 7 \\
\hline $\begin{array}{l}7 \\
6\end{array}$ & $\begin{array}{l}\text { 5‘ GCGTTA EEEE } \\
\text { 3، CGCAAT EEEE }\end{array}$ & 52.0 & 0 \\
\hline $\begin{array}{l}1 \\
7\end{array}$ & $\begin{array}{l}\text { 5‘ GCGTTA YYYY } \\
5^{\prime} \text { GCGTTA EEEE }\end{array}$ & $--^{b}$ & $\mathrm{n} / \mathrm{a}$ \\
\hline $\begin{array}{l}2 \\
6\end{array}$ & $\begin{array}{l}\text { 3' CGCAAT YYYY } \\
\text { 3‘ CGCAAT EEEE }\end{array}$ & $-^{b}$ & $\mathrm{n} / \mathrm{a}$ \\
\hline
\end{tabular}

aConditions: oligomer conc. $2.5 \mu \mathrm{M}$ single strand, $10 \mathrm{mM}$ sodium phosphate buffer, $\mathrm{pH} 7.2,0.1 \mathrm{M} \mathrm{NaCl}$, absorption monitored at $260 \mathrm{~nm}$; error $\pm 0.5^{\circ} \mathrm{C}$; ${ }^{b}$ no transition observed (see Supporting Information File 1).

The DNA stem acts as a supramolecular scaffold, and together with the flexible, negatively-charged phosphate linker allows the chromphores to adopt optimal conformations in aqueous solution and increases the solubility. The strands were hybridised in various combinations (Table 1), and their stability and photophysical properties were investigated. Since the DNA duplex is identical in all hybrids, differences in stability must originate from the modified section. The sequence of the modified part is changed in such a way that annealing of different strands leads to a varying number of pyrene-PDI stacking interactions. Strand $\mathbf{1}$ is common to all hybrids. The complementary strands 2-6 possess an increasing number of PDIs. Thus, in the resultant hybrids, the number of pyrene-PDI face-to-face stacking interactions also increases steadily from left to right, e.g., duplex $1 * 2$ contains only pyrene-pyrene interactions, whereas duplex $1 * 6$ has the maximum number pyrene-PDI interactions.

\section{Thermal denaturation experiments}

Thermal denaturation experiments revealed a clear trend in duplex stability (Figure 2). The thermal stability correlates with the number of pyrene-PDI interactions [56] and increases linearly in the series. The melting temperature $\left(T_{\mathrm{m}}\right)$ values are summarized in Table 1. 
A
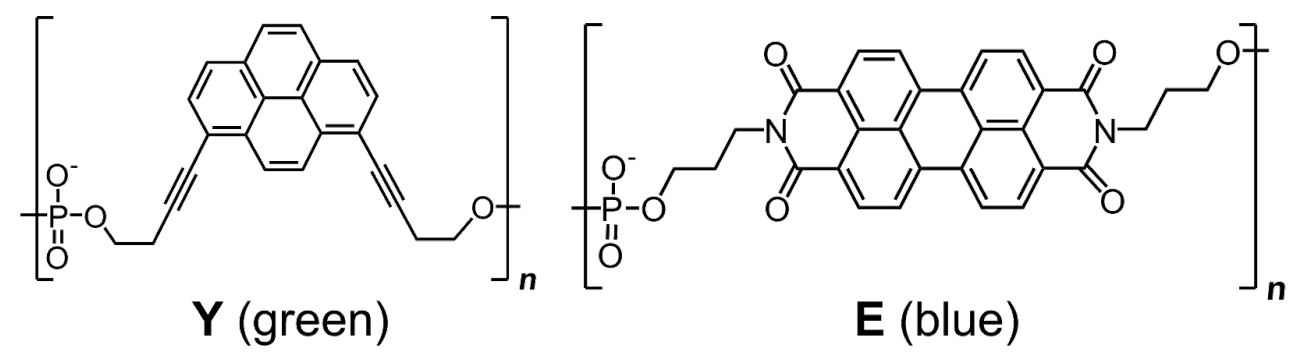

B
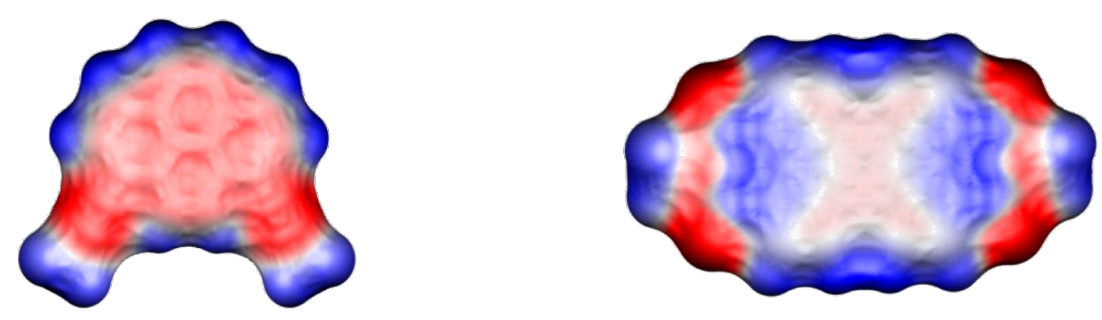

C
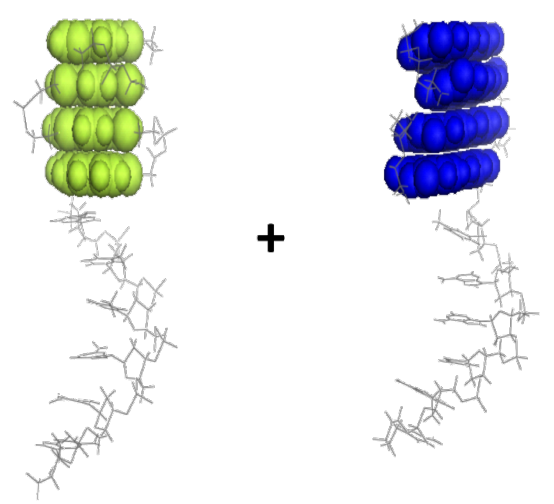

1

6

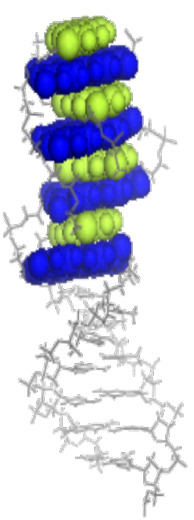

$1^{*} 6$

D
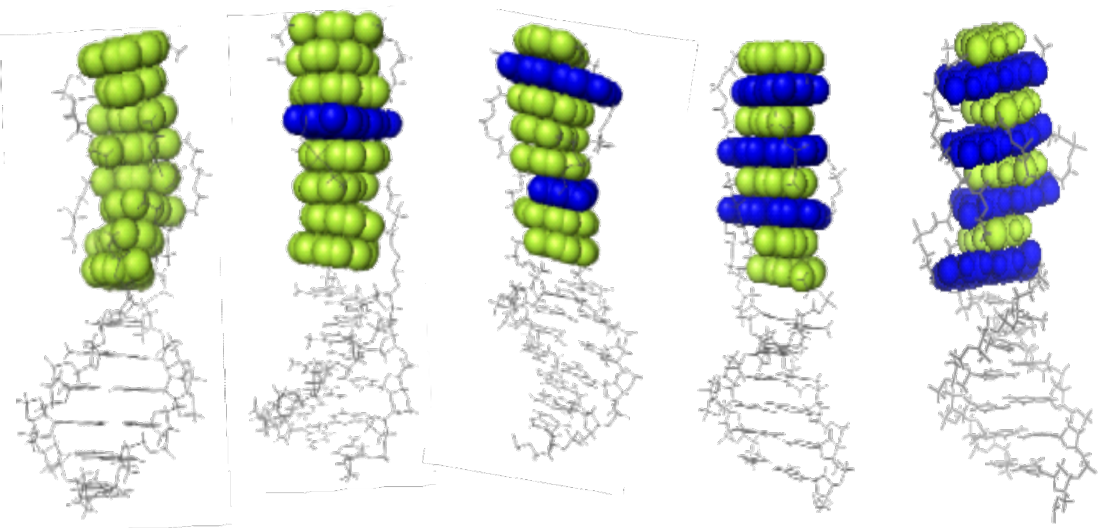

$1 * 2$

Figure 1: (A) Structures of 1,8-dialkynylpyrene (Y) and PDI (E); (B) illustration of the electrostatic potential surface of 1,8-diprop-1-ynylpyrene (left) and $N, N$-dimethyl-PDI (right); (C) illustration of duplex formation with chimeric oligomers; (D) hybrids $1 * 2$ to $1^{*} 6$. The number of pyrene-PDI interactions increases from left to right. 


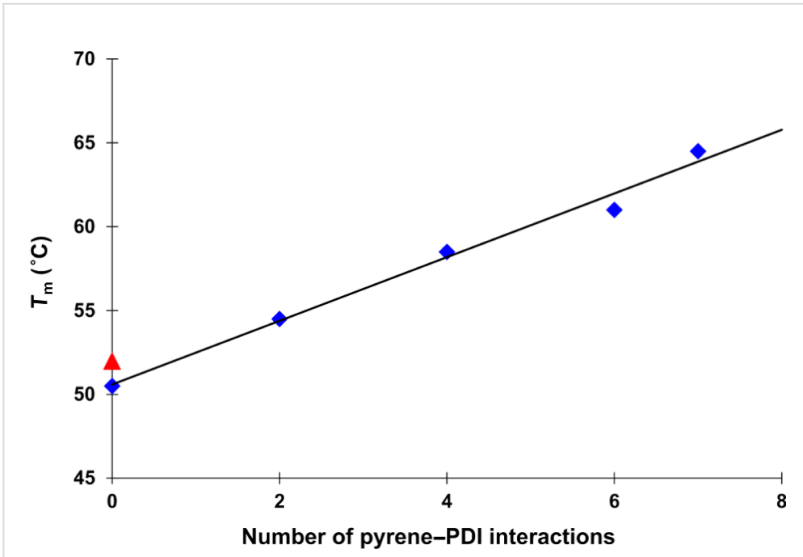

Figure 2: A plot of melting temperature $\left(T_{\mathrm{m}}\right)$ versus the number of pyrene-PDI interactions for duplexes $1 * 2$ to $\mathbf{1}^{*} \mathbf{6}$ (from left to right) presented in Table 1. The $T_{\mathrm{m}}$ was recorded at $260 \mathrm{~nm} ; \mathrm{R}^{2}=0.987$ The red triangle represents the $T_{\mathrm{m}}$ of the control hybrid $7^{*} 6$.

Hybrid $\mathbf{1}^{*} \mathbf{2}$ has a $T_{\mathrm{m}}$ of $50.5^{\circ} \mathrm{C}$ which is $37.5^{\circ} \mathrm{C}$ higher than the reference DNA duplex $\left(T_{\mathrm{m}}=13{ }^{\circ} \mathrm{C}\right)$. Since hybrid $\mathbf{1}^{* \mathbf{2}}$ has seven pyrene-pyrene interactions, one of these interactions $\left(\Delta T_{\mathrm{m} /(\mathrm{Y}-\mathrm{Y})}\right)$ contributes $\approx 5.4{ }^{\circ} \mathrm{C}$ to hybrid stability. Likewise, a value for $\Delta T_{\mathrm{m} /(\mathrm{E}-\mathrm{E})}=5.6{ }^{\circ} \mathrm{C}$ is calculated for hybrid $7 * 6$. The average contribution of a pyrene-PDI interaction can be calculated from the $T_{\mathrm{m}}$ difference $\left(T_{\mathrm{m}}=51.5^{\circ} \mathrm{C}\right)$ between $1^{*} \mathbf{6}$ and the reference duplex. A value of $\Delta T_{\mathrm{m} /(\mathrm{Y}-\mathrm{E})}=7.4{ }^{\circ} \mathrm{C}$ is obtained in this way. Hybrid $7 * 2$ serves as a further control. In this duplex, the DNA and the modified parts of the two strands have been interchanged relative to $\mathbf{1}^{*} \mathbf{6}$. The $T_{\mathrm{m}}$ value of $\mathbf{7}^{*} \mathbf{2}$ is in the same range as $1 * 6\left(66.5\right.$ and $64.5{ }^{\circ} \mathrm{C}$, respectively), which translates into $\Delta T_{\mathrm{m} /(\mathrm{Y}-\mathrm{E})}=7.7^{\circ} \mathrm{C}$. Thus, the average contributions to the hybrid stabilities are as follows: $\Delta T_{\mathrm{m} /(\mathrm{Y}-\mathrm{E})} \approx 7.5^{\circ} \mathrm{C}$, whereas $\Delta T_{\mathrm{m} /(\mathrm{Y}-\mathrm{Y})}$ and $\Delta T_{\mathrm{m} /(\mathrm{E}-\mathrm{E})} \approx 5.5^{\circ} \mathrm{C}$.

The results of electrostatic complementarity between an electron-rich pyrene and an electron-poor PDI is highlighted by the fact that duplexes with only pyrene or PDI are considerably less stable (Table 1 , hybrids $1 * \mathbf{2}$ and $7 * \mathbf{6}$ ) than hybrids containing both types of aromatic compounds. Although the actual stability of such duplexes strongly depends on several parameters like, e.g., the geometry of the building blocks and the flexibility of the linkers, a general trend can be deduced from the thermal denaturation results that accounts for the above mentioned design of building blocks and sequences.

\section{UV-vis absorption spectroscopy}

The stacking interactions of $\mathbf{Y}$ and $\mathbf{E}$ in the hybrids could be followed by UV-vis absorption spectroscopy. A significant change in the vibronic band ratio supports the model of an alternating interstrand interdigitation interaction between pyrene and PDI chromophores as proposed in Figure 1. In general, the vibronic band ratio of PAHs gives valuable information on the aggregation state of the molecules [57]. In a stack of only pyrenes $(1 * 2)$ the vibronic band at $370 \mathrm{~nm}$ is higher than that at $390 \mathrm{~nm}$ (Figure 3), indicating that the pyrenes are stacked parallel and face-to-face. In contrast, in duplex $1 * 6$ the intensity of the vibronic band $390 \mathrm{~nm}$ is higher indicating that the pyrenes are separated from each other by intercalating PDIs [58]. The same absorption behaviour is seen for the PDI vibronic band intensities.

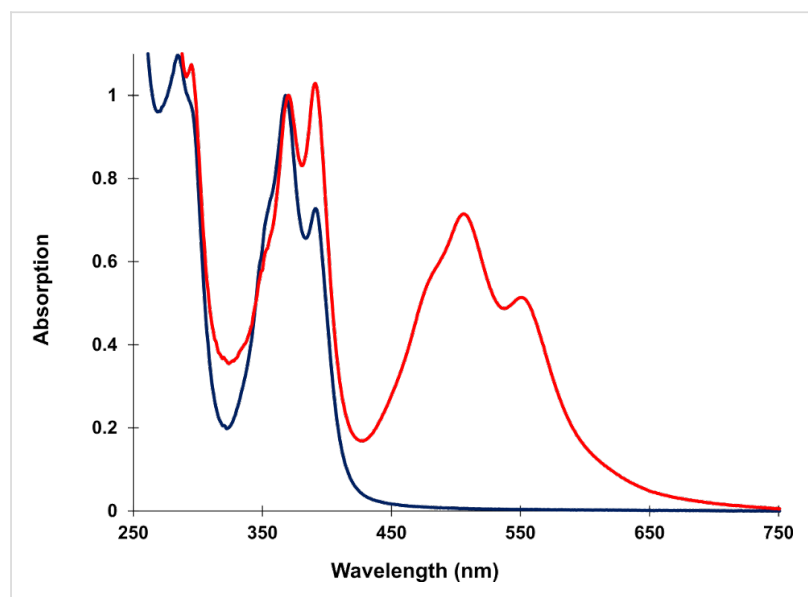

Figure 3: UV-vis absorption spectra (scaled) of duplexes 1*2 (blue) and $1^{*} 6$ (red) at $20^{\circ} \mathrm{C}$. Conditions: see Table 1.

Figure 4 focuses on the vibronic bands of pyrene's $S_{0} \rightarrow S_{1}$ absorption band in duplexes $1 * \mathbf{2}$ to $\mathbf{1} * \mathbf{6}$. An increasing number of PDIs in a stack leads to a stronger vibronic band at $390 \mathrm{~nm}$.

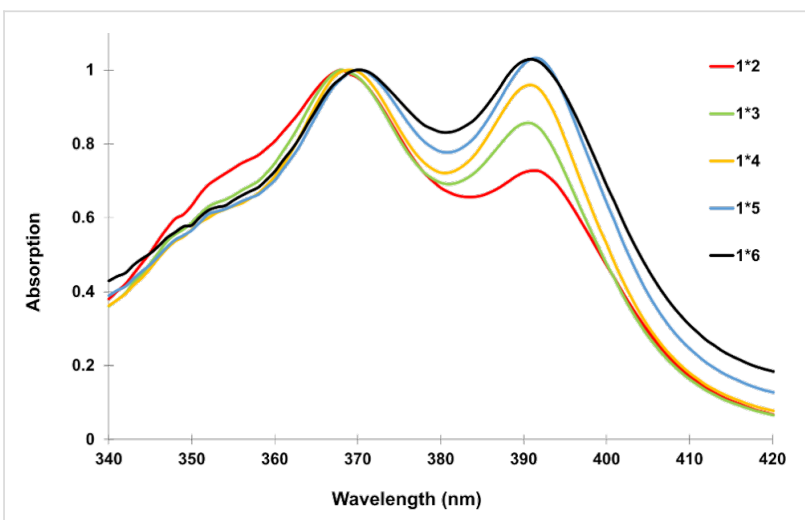

Figure 4: UV-vis absorption spectra (scaled) of duplexes $\mathbf{1}^{\star} \mathbf{2}$ to $\mathbf{1}^{\star} \mathbf{6}$ at $20^{\circ} \mathrm{C}$. Conditions: see Table 1.

This is in stark contrast to the effect of thermally denaturing duplex $1 * 2$ into two single strands (Figure 5). There, the vibronic band at $370 \mathrm{~nm}$ is always the highest indicating that the pyrenes are stacked even at $90{ }^{\circ} \mathrm{C}$ in the single strands. Such behaviour was also observed in chrysene-modified DNA [59]. 


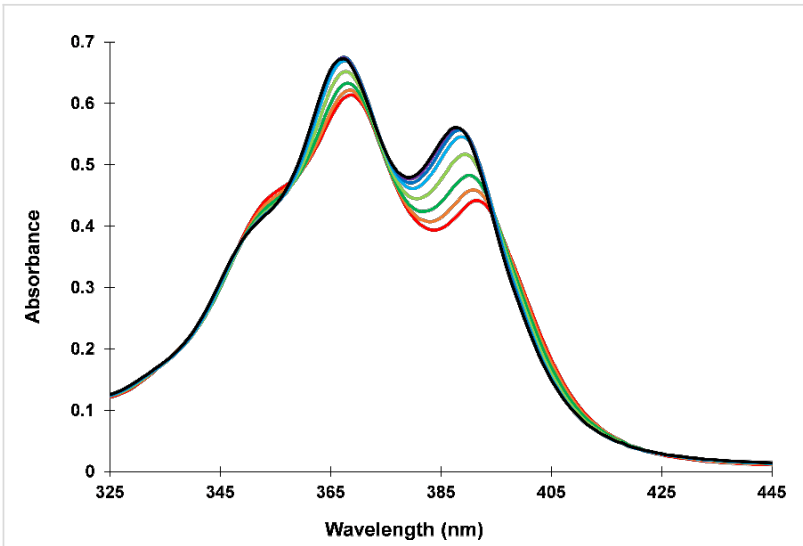

Figure 5: Temperature-dependent UV-vis absorption spectrum of $\mathbf{1}$ ². Conditions: see Table 1.

\section{Fluorescence spectroscopy}

The interaction of two or more dialkynylpyrenes $(\mathbf{Y})$ results in a pronounced excimer fluorescence [53]. Hybridization of single strands 1 and $\mathbf{2}$ increases the intensity of the excimer (Figure 6), whereas hybridization of single strands $\mathbf{1}$ and $\mathbf{6}$ results in an extinction of excimer fluorescence. Such behaviour was also observed in previous work and was explained by an alternating interdigitation interaction of the pyrene with the PDI building blocks [60].

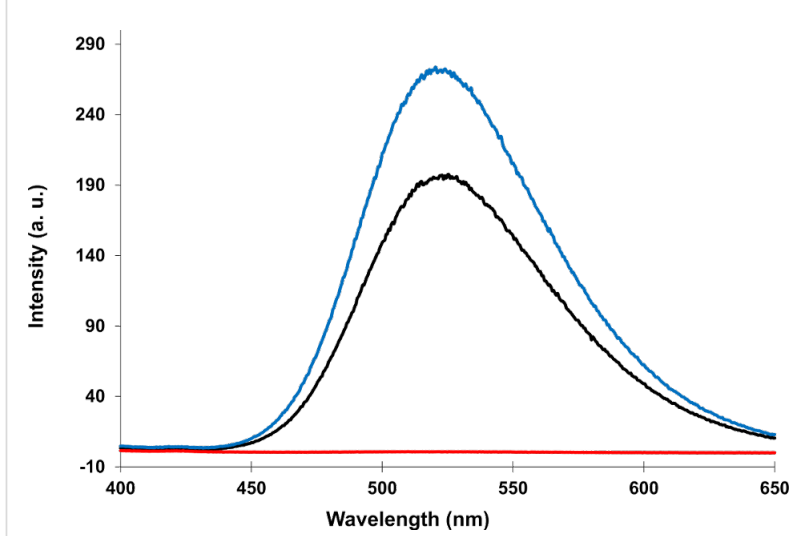

Figure 6: Fluorescence spectra of oligomer 1 (black), duplex $\mathbf{1}$ 2 (blue) and duplex $1^{*} \mathbf{6}$ (red) at $20^{\circ} \mathrm{C}$. Excitation: $370 \mathrm{~nm}$. Conditions: see Table 1.

\section{Gel migration experiments}

The electrophoretic mobility of relatively small (<1000 kbp), linear DNA strands is inversely proportional to their molecular weight [61]. It serves as a reliable method to demonstrate the formation of double versus single stranded DNA structure. Therefore, the formation of defined short duplexes has been further investigated using polyacrylamide gel electrophoresis (PAGE) experiments. Oligomer single strands 1, 6 and 7 migrate with the same velocity as the $13 \mathrm{bp}$ reference (Figure 7). Strands 1 and 6, however, form a duplex and thus have lower electrophoretic mobility, similar to an 18-20 bp reference. Oligomer 7 has the same DNA sequence as $\mathbf{6}$, but with 4 PDI molecules instead of 4 pyrenes (see Table 1). Thus when combined, single strands $\mathbf{1}$ and $\mathbf{7}$ do not form a duplex due to having non-complementary DNA parts, and migrate on the gel like single strands $\mathbf{1}, \mathbf{6}$, and $\mathbf{7}$. These results underline the importance of the complementary DNA segments in aligning the pyrene and PDI chromophores for optimal interaction.

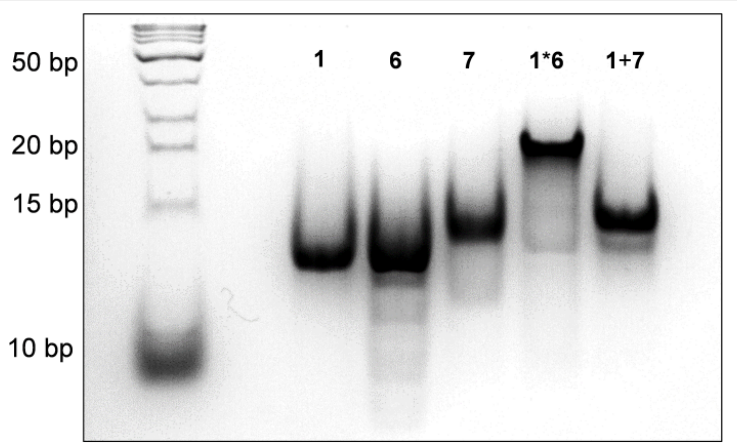

Figure 7: PAGE experiment. All oligomers were used in a total amount of $150 \mathrm{pmol}$ in $10 \mathrm{mM}$ sodium phosphate buffer, $100 \mathrm{mM} \mathrm{NaCl}$ and $10 \%$ loading buffer, $20 \%$ polyacrylamide gel with a $10 \%$ loading gel, $1 \mathrm{~h} 40 \mathrm{~min}, 4^{\circ} \mathrm{C}, 170 \mathrm{~V}, 6 \mathrm{~mA}, 2 \mathrm{~W}$. Left lane: DNA ladder.

\section{Conclusion}

A series of DNA oligonucleotides functionalised with electronpoor perylenediimide (PDI, E) and electron-rich 1,8dialkynylpyrene (Y) chromophores has been synthesized and their photophysical and thermal melting properties were investigated. UV-vis absorption and fluorescence spectra indicate an alternate, face-to-face, stacking of PDI and pyrene moieties. The DNA portion serves as an ideal scaffold to align the pyrene and PDI chromophores and to study their interaction in solution. The stability of the duplexes shows a clear dependence on the number of pyrene-PDI interactions within the duplex. As the pyrene-PDI ratio approaches $1: 1$, the stability of the duplexes increases with up to $7.5{ }^{\circ} \mathrm{C}$ per pyrene-PDI supramolecular interaction underlining the importance of electrostatic complementarity for aromatic $\pi-\pi$ stacking interactions.

\section{Supporting Information}

\section{Supporting Information File 1}

Detailed experimental procedures and supplementary spectroscopic data.

[http://www.beilstein-journals.org/bjoc/content/ supplementary/1860-5397-10-164-S1.pdf] 


\section{Acknowledgements}

We would like to express our sincere gratitude to Prof. Dr. Gion Calzaferri for invaluable suggestions and discussions regarding this work. This work was supported by the Swiss National Foundation (Grant 200020-149148).

\section{References}

1. Hunter, C. A.; Sanders, J. K. M. J. Am. Chem. Soc. 1990, 112, 5525-5534. doi:10.1021/ja00170a016

2. Hunter, C. A.; Lawson, K. R.; Perkins, J.; Urch, C. J. J. Chem. Soc., Perkin Trans. 2 2001, 651-669. doi:10.1039/b008495f

3. Salonen, L. M.; Ellermann, M.; Diederich, F. Angew. Chem., Int. Ed. 2011, 50, 4808-4842. doi:10.1002/anie.201007560

4. Grimme, S. Angew. Chem., Int. Ed. 2008, 47, 3430-3434. doi:10.1002/anie.200705157

5. Martinez, C. R.; Iverson, B. L. Chem. Sci. 2012, 3, 2191-2201. doi:10.1039/c2sc20045g

6. Watson, M. D.; Fechtenkötter, A.; Müllen, K. Chem. Rev. 2001, 101, 1267-1300. doi:10.1021/cr990322p

7. Feng, C.; Lin, C. S.; Fan, W.; Zhang, R. Q.; Van Hove, M. A. J. Chem. Phys. 2009, 131, 194702. doi:10.1063/1.3251785

8. Hunter, C. A. Chem. Soc. Rev. 1994, 23, 101-109. doi:10.1039/cs9942300101

9. Meyer, E. A.; Castellano, R. K.; Diederich, F. Angew. Chem., Int. Ed. 2003, 42, 1210-1250. doi:10.1002/anie.200390319

10. Hunter, C. A. J. Mol. Biol. 1993, 230, 1025-1054. doi:10.1006/jmbi.1993.1217

11. Philp, D.; Stoddart, J. F. Angew. Chem., Int. Ed. Engl. 1996, 35, 1154-1196. doi:10.1002/anie.199611541

12. Sakai, N.; Matile, S. Beilstein J. Org. Chem. 2012, 8, 897-904. doi:10.3762/bjoc.8.102

13. Cockroft, S. L.; Perkins, J.; Zonta, C.; Adams, H.; Spey, S. E.; Low, C. M. R.; Vinter, J. G.; Lawson, K. R.; Urch, C. J.; Hunter, C. A. Org. Biomol. Chem. 2007, 5, 1062-1080. doi:10.1039/b617576g

14. Wheeler, S. E. Acc. Chem. Res. 2013, 46, 1029-1038. doi:10.1021/ar300109n

15. Collings, J. C.; Roscoe, K. P.; Robins, E. G.; Batsanov, A. S.; Stimson, L. M.; Howard, J. A. K.; Clark, S. J.; Marder, T. B. New J. Chem. 2002, 26, 1740-1746. doi:10.1039/b207102a

16. Ponzini, F.; Zagha, R.; Hardcastle, K.; Siegel, J. S. Angew. Chem., Int. Ed. 2000, 39, 2323-2325. doi:10.1002/1521-3773(20000703)39:13<2323::AID-ANIE2323>3.0.CO ;2-X

17. Lokey, R. S.; Iverson, B. L. Nature 1995, 375, 303-305. doi:10.1038/375303a0

18. Gabriel, G. J.; Sorey, S.; Iverson, B. L. J. Am. Chem. Soc. 2005, 127, 2637-2640. doi:10.1021/ja046722y

19. Mathis, G.; Hunziker, J. Angew. Chem., Int. Ed. 2002, 41, 3203-3205. doi:10.1002/1521-3773(20020902)41:17<3203::AID-ANIE3203>3.0.CO ;2-K

20. Tanaka, H.; Bollot, G.; Mareda, J.; Litvinchuk, S.; Tran, D.-H.; Sakai, N.; Matile, S. Org. Biomol. Chem. 2007, 5, 1369-1380. doi:10.1039/b702255g

21. Das, A.; Molla, M. R.; Maity, B.; Koley, D.; Ghosh, S. Chem.-Eur. J. 2012, 18, 9849-9859. doi:10.1002/chem.201201140

22. Ghosh, S.; Ramakrishnan, S. Macromolecules 2005, 38, 676-686. doi: $10.1021 / \mathrm{ma} 0478759$
23. Hunter, C. A. BioEssays 1996, 18, 157-162. doi:10.1002/bies.950180212

24. Eschenmoser, A. Science 1999, 284, 2118-2124. doi:10.1126/science.284.5423.2118

25. Kool, E. T. Chem. Rev. 1997, 97, 1473-1488. doi:10.1021/cr9603791

26. Herdewijn, P. Biochim. Biophys. Acta, Gene Struct. Expression 1999, 1489, 167-179. doi:10.1016/S0167-4781(99)00152-9

27. Benner, S. A. Acc. Chem. Res. 2004, 37, 784-797. doi:10.1021/ar040004z

28. Wengel, J. Acc. Chem. Res. 1999, 32, 301-310. doi:10.1021/ar980051p

29. Benner, S. A.; Hutter, D. Bioorg. Chem. 2002, 30, 62-80. doi:10.1006/bioo.2001.1232

30. Yang, Z. Y.; Hutter, D.; Sheng, P.; Sismour, A. M.; Benner, S. A. Nucleic Acids Res. 2006, 34, 6095-6101. doi:10.1093/nar/gkl633

31. Hirao, I.; Kimoto, M.; Yamashige, R. Acc. Chem. Res. 2012, 45 , 2055-2065. doi:10.1021/ar200257x

32. Wu, Y. Q.; Ogawa, A. K.; Berger, M.; McMinn, D. L.; Schultz, P. G.; Romesberg, F. E. J. Am. Chem. Soc. 2000, 122, 7621-7632. doi:10.1021/ja0009931

33. Berger, M.; Ogawa, A. K.; McMinn, D. L.; Wu, Y.; Schultz, P. G.; Romesberg, F. E. Angew. Chem., Int. Ed. 2000, 39, 2940-2942. doi:10.1002/1521-3773(20000818)39:16<2940::AID-ANIE2940>3.0.CO ;2-\#

34. Liu, H.; Gao, J.; Maynard, L.; Saito, Y. D.; Kool, E. T. J. Am. Chem. Soc. 2004, 126, 1102-1109. doi:10.1021/ja038384r

35. Brotschi, C.; Häberli, A.; Leumann, C. J. Angew. Chem., Int. Ed. 2001, 40, 3012-3014. doi:10.1002/1521-3773(20010817)40:16<3012::AID-ANIE3012>3.0.CO ;2-Y

36. Lokey, R. S. Curr. Opin. Chem. Biol. 2003, 7, 91-96. doi:10.1016/S1367-5931(02)00002-9

37. Ikkanda, B. A.; Samuel, S. A.; Iverson, B. L. J. Org. Chem. 2014, 79, 2029-2037. doi:10.1021/j0402704z

38. Hecht, S.; Huc, I., Eds. Foldamers - Structure, Properties, and Applications; Wiley-VCH: Weinheim, 2007.

39. Filichev, V. V.; Pedersen, E. B. DNA-Conjugated Organic Chromophores in DNA Stacking Interactions. In Wiley Encyclopedia of Chemical Biology; Begley, T. P., Ed.; Wiley: Hoboken, 2009; Vol. 1.

40. Varghese, R.; Wagenknecht, H.-A. Chem. Commun. 2009, 2615-2624 doi:10.1039/b821728a

41. Malinovskii, V. L.; Wenger, D.; Häner, R. Chem. Soc. Rev. 2010, 39, 410-422. doi:10.1039/b910030j

42. Østergaard, M. E.; Hrdlicka, P. J. Chem. Soc. Rev. 2011, 40, 5771-5788. doi:10.1039/c1cs15014f

43. Stulz, E. Chem.-Eur. J. 2012, 18, 4456-4469. doi:10.1002/chem.201102908

44. Asanuma, H.; Fujii, T.; Kato, T.; Kashida, H. J. Photochem. Photobiol., C 2012, 13, 124-135. doi:10.1016/j.jphotochemrev.2012.04.002

45. Häner, R.; Garo, F.; Wenger, D.; Malinovskii, V. L. J. Am. Chem. Soc. 2010, 132, 7466-7471. doi:10.1021/ja102042p

46. Rudnev, A. V.; Malinovskii, V. L.; Nussbaumer, A. L.; Mishchenko, A.; Häner, R.; Wandlowski, T. Macromolecules 2012, 45, 5986-5992. doi:10.1021/ma3007619

47. Simona, F.; Nussbaumer, A. L.; Häner, R.; Cascella, M. J. Phys. Chem. B 2013, 117, 2576-2585. doi:10.1021/jp310320f

48. Häner, R.; Samain, F.; Malinovskii, V. L. Chem.-Eur. J. 2009, 15, 5701-5708. doi:10.1002/chem.200900369 
49. Langhals, H. Helv. Chim. Acta 2005, 88, 1309-1343. doi:10.1002/hlca.200590107

50. Weil, T.; Vosch, T.; Hofkens, J.; Peneva, K.; Müllen, K. Angew. Chem., Int. Ed. 2010, 49, 9068-9093. doi:10.1002/anie.200902532

51. Würthner, F. Chem. Commun. 2004, 1564-1579. doi:10.1039/b401630k

52. Neelakandan, P. P.; Zeidan, T. A.; McCullagh, M.; Schatz, G. C.; Vura-Weis, J.; Kim, C. H.; Wasielewski, M. R.; Lewis, F. D. Chem. Sci. 2014, 5, 973-981. doi:10.1039/c3sc52908h

53. Bittermann, H.; Siegemund, D.; Malinovskii, V. L.; Häner, R. J. Am. Chem. Soc. 2008, 130, 15285-15287. doi:10.1021/ja806747h

54. Vybornyi, M.; Rudnev, A. V.; Langenegger, S. M.; Wandlowski, T.; Calzaferri, G.; Häner, R. Angew. Chem., Int. Ed. 2013, 52, 11488-11493. doi:10.1002/anie.201307029

55. Rahe, N.; Rinn, C.; Carell, T. Chem. Commun. 2003, 2120-2121. doi:10.1039/B307395E

56. It must be noted at this point, that the exact sequence of pyrene/PDI alternation can only be guessed, since the first residue stacking on the DNA stem could belong to either of the two strands. To simplify all subsequent description and discussion we have chosen that the first modified residue is the one attached at the nucleotide 5 '-position.

57. Clark, A. E.; Qin, C.; Li, A. D. Q. J. Am. Chem. Soc. 2007, 129, 7586-7595. doi:10.1021/ja0687724

58. Biner, S. M.; Kummer, D.; Malinovskii, V. L.; Häner, R. Org. Biomol. Chem. 2011, 9, 2628-2633. doi:10.1039/c0ob01132k

59. Khorev, O.; Bösch, C. D.; Probst, M.; Häner, R. Chem. Sci. 2014, 5, 1506-1512. doi:10.1039/c3sc53316f

60. Bouquin, N.; Malinovskii, V. L.; Häner, R. Chem. Commun. 2008, 1974-1976. doi:10.1039/b802193g

61. Bloomfield, V. A.; Crothers, D. M.; Tinoco, I., Jr. Nucleic Acids Structures, Properties, and Functions; University Science Books: Sausalito, CA, 2000.

\section{License and Terms}

This is an Open Access article under the terms of the Creative Commons Attribution License (http://creativecommons.org/licenses/by/2.0), which permits unrestricted use, distribution, and reproduction in any medium, provided the original work is properly cited.

The license is subject to the Beilstein Journal of Organic Chemistry terms and conditions:

(http://www.beilstein-journals.org/bjoc)

The definitive version of this article is the electronic one which can be found at: $\underline{\text { doi:10.3762/bjoc. } 10.164}$ 